\title{
STERNUM AS AN INDEX FOR DETERMINATION OF SEX
}

\section{Rashmi Jaiswal}

Assistant Professor, Department of Anatomy, Chirayu Medical College and Hospital, Bhopal (MP), 462030, India.

\section{ABSTRACT}

Background: To examine human bones is a challenge for experts, especially in deceased and also for determination of sex for medico-legal purpose. Measurement of the sternum is done by many authors for determination of sex. Sternum was measured for length of manubrium, length of mesosternum and combined length of manubrium and mesosternum. The data was statistically analysed.

Method: The present study was done on 65 human sternums(46 Males and 19 Females). Sternum was extracted from cadavers in the Department of Anatomy, People's College of Medical Sciences and Research Centre, Bhopal and Sternum from Autopsy bodies in the Department of Forensic Medicine and Toxicology, People's College of Medical Sciences and Research Centre, Bhopal. (MP),India.

Results: If the combined length of a sternum is less than $150 \mathrm{~mm}$ then it is of female sternum, if it exceeds $150 \mathrm{~mm}$, it is of male sternum. The mean Sternal Index in male was 43.43 and in females $41.132 .89 .13 \%$ of male and $21.05 \%$ of female specimen obey the Hyrtl's law.

Conclusion: The combined length of manubrium and mesosternum is considered as the most important parameter, which when applied to an individual specimen can help in sexing the sterna correctly in our study.

KEY WORDS: Manubrium sterni, Mesosternum or Body of sternum, Sternal angle, Sternal Index.

Corresponding Author: Dr. Rashmi Jaiswal, 185, Rachna Nagar,Bhopal (MP), 462023, India. Mobno-09425029067 E-Mail: rashmijwal@yahoo.com

Access this Article online

Quick Response code

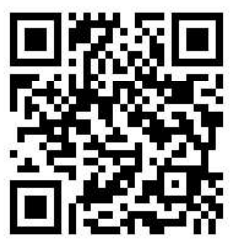

DOI: $10.16965 /$ ijar.2019.307
Journal Information

\section{International Journal of Anatomy and Research}

ICV for 2016 ISSN (E) 2321-4287 | ISSN (P) 2321-8967

90.30

https://www.ijmhr.org/ijar.htm

DOI-Prefix: https://dx.doi.org/10.16965/ijar

\section{Article Information}

Received: 02 Sep 2019

Peer Review: 03 Sep 2019

Revised: None
Accepted: 09 Oct 2019

Published (O): 05 Nov 2019

Published (P): 05 Nov 2019

\section{INTRODUCTION}

Lot of work has been done and ample literature is available in anatomy and anthropology for identification of human skeleton. For medicolegal purposes, examination of human skeleton is a important part. To know whether the bone is of male or the female from unknown human skeletal or decomposed bodies is an important step in forensic investigation and also to know correct age and sex of specimen. If whole skeleton is available for examination, we can identify the sex (male/ female) with $100 \%$ accuracy. When only skull or pelvis is available, sex can be determined with $90 \%$ accuracy. If no skull and pelvis is available, it becomes difficult to know the age and sex accurately[1]. To know $100 \%$ accuracy in determining the sex, it depends on the nature of material available and methods applied.

Measurement of human sternum as an individual parameter for determination of age and sex has been done by many workers. Wenzel (1788) recorded data for the first time. He concludes that the difference in the ratio between the length of manubrium and that of mesosternum in both sexes. Following him, further studies done by Fiegel (1837), Dwight (1890), and Ashley (1956). In the present study, length of manubrium, length of mesosternum and combined length of manubrium and mesosternum 
were measured and determination of sex done by human sternum.

The osseous skeleton of sternum is the only structure which resists the effect of putrefaction and decomposition for longer time. The ratio between manubrial and mesosternal lengths differs in the males and female sternum. Sternum is useful for determination of sex of an individual. Studies done on human sternum reported in both sexes of American, African and European population and also in different zones of Indian population like North Indian, Maharashtra and Gujarati population. Ashley (1956) [2] studied the combined length of manubrium and body of sternum in both male and female in European population. He forwarded "rule of 149", if the combined length of manubrium and mesosternum is more than $149 \mathrm{~mm}$ then sternum of male and if less than $149 \mathrm{~mm}$, then sternum was female but it is not applicable for African population, so new rule of "136" (1956) [2] for African Population.

Sternum: The sternum consists of a cranial manubrium (prosternum), an intermediate body (mesosternum), and a caudal xiphoid process or xiphisternum (metasternum). The mesosternum consists of four sternebrae, from its costal relations. The length of the male sternum is $17 \mathrm{~cm}$ and less in female sternum. The ratio between manubrial and mesosternal lengths differs between the two sexes. Growth may continue beyond the third decade and possibly throughout life.

In natural stance, the sternum slopes down and slightly forwards. It is convex in front, concave behind, and broadest at the junction with the first costal cartilages. It is narrowest at the manubriosternal joint, andnarrows below the fifth cartilages. The sternum has highly vascular trabecular bone enclosed by a compact layer which is thickest in the manubrium. The medulla contains red bone marrow.

\section{MATERIALS AND METHODS}

Human Sternum from cadavers in the Department of Anatomy and Sternum from Autopsy bodies which were brought for medico-legal post- mortem examination in the Department of Forensic Medicine and Toxicology, People's College of Medical Sciences and Research
Centre, Bhopal, (MP), (From February 2014 to August 2015).

All the sternum to be examined with inclusion criteria, which came for autopsy and those of dissection cadavers have been included in the study.

Fig. 1: Vernier Caliper.

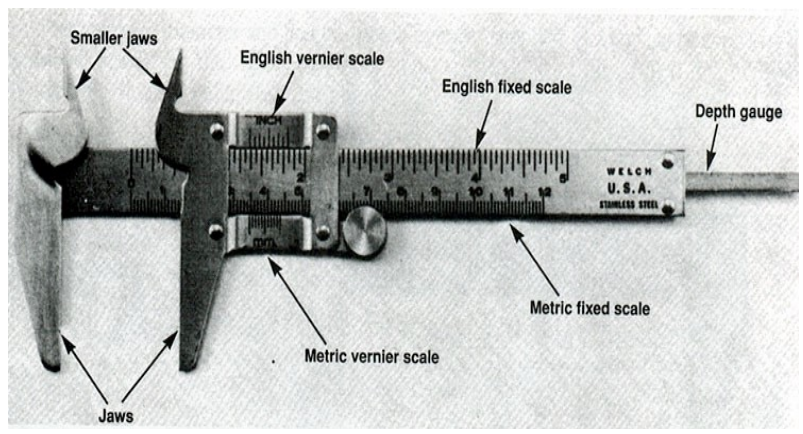

Fig. 2: Measurements of Sternum X1, X2, X3.

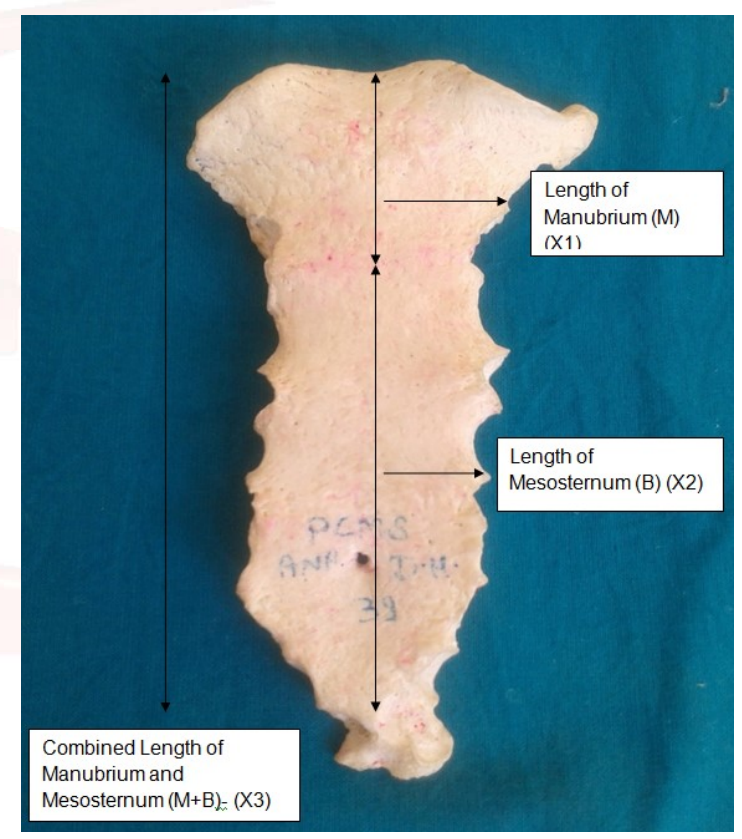

Study material -Human Sternum

Study sample - 65 sternums(46 Males and 19 Females)

Technique - The sterna were removed from the cadavers by sectioning the costal cartilages just beside the costo-chondral junction.

Inclusion Criteria - Sterna without any obvious pathology above the age of 10 years.

Exclusion Criteria - Deformed sternum, Diseased sternum and Fractured sternum.

Measurements were taken in millimetres, with the help of Vernier Caliper-

1. Length of manubrium (M) - It is the distance from suprasternal notch to Manubriomesosternal junction in midline. (X1) 
2. Length of mesosternum (B) - It is the distance from manubrio-mesosternal junction to the mesosterno-xiphoidal junction in the midline. (X2)

\section{Combined length of manubrium and mesosternum $=M+B(X 3)$}

4. Manubrio-corpus index $(X 6)=$ Length of manubrium (M) / Length of mesosternum (B) $\times 100$

\section{Instrument used - Vernier Caliper}

The vernier caliper is a slide-type calliper used to take inside, outside, and depth measurements. The vernier caliper has two metric scales and two English scales.

\section{RESULTS}

Length of Manubrium: The present study indicate that the difference between the average length of male and female manubria is $3.26 \mathrm{~mm}$, which is statistically not significant $(p=0.07)$, thus the measurement of Length of Manubrium is least helpful for sexing sternum.

Length of Mesosternum: In present study, the average difference in the length of (Body of sternum)mesosternum between the male and female sternum is $2.4 \mathrm{~mm}$ which is statistically significant $(p=0.001)$, the length of mesosternum is useful in determining the sex of sterna, because the length of mesosternum is more than the length of manubrium in male sternum.

Combined Length of the manubrium and Mesosternum: In our study, the difference between the average combined length of manubrium and mesosternum in male and female sternum is $5.407 \mathrm{~mm}$ which is statistically significant $(p=0.001)$. The co-extensive range is $153.087-147.087 \mathrm{~mm}$, is very useful in determination of sex of sternum.

All the above observations are given in Table number 1

Manubrio - Corpus index (Sternal Index): Mean sternal index difference in male sternum and female sternum was 2.306. In the present study, $21.05 \%$ female and $89.13 \%$ male specimens obey the Hyrtl's law. p value 0.8 , which is not significant, this law is not helpful in determining the sex.

Discriminant Function Analysis Results: To define classification of the bones and to discriminate between sexes of the sterna, Fischer's Discriminant to all metric observations of all the paramaters, two variables can identify the sex category of the studied bones. The discrimination method was based on Wilk's lamda criteria.

The discriminate analysis done by given formula -

$D=(2.348 \times$ Manubrium length $)+(2.697 \times$ Mesosternal length $)+(-3.302 \times$ Combined length of manubrium and mesosternum)

Centroid of cut off taken as

$-\frac{0.149+(-0.361)}{2}=(-0.106)$

When $D$ is more than -0.106 , it is male sternum When $D$ is less than -0.106 , it is female sternum

$61.5 \%$ were classified correctly.

$\begin{array}{lll}\text { Sensitivity } & - & 56.5 \% \\ \text { Specificity } & - & 73.7 \% \\ \text { Positive Predicted Value } & - & 83.87 \% \\ \text { Negative Predicted Value } & - & 41.17 \%\end{array}$

\section{OBSERVATIONS}

Fig. 3: Length of Manubrium (M )-(X1).

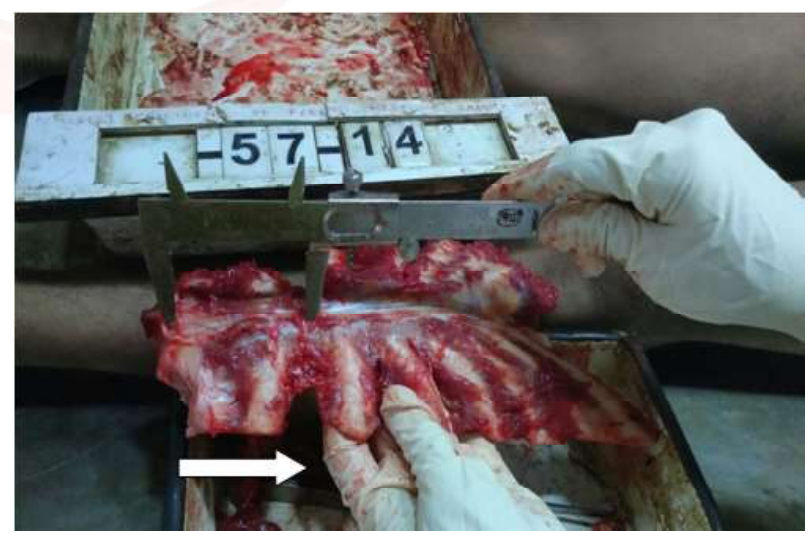

Fig. 3: Length of Manubrium (M )-(X1).

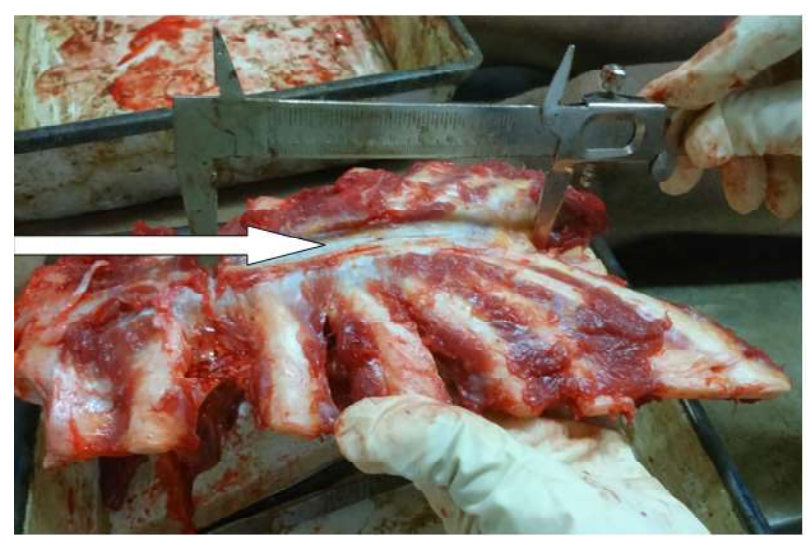


Table 1: Various measurements of the sterna in the Males and Females.

\begin{tabular}{|c|c|c|c|c|c|c|}
\hline Parameter & Sex & Range & Mean & SD & t test & $\begin{array}{c}\text { Level of significance for } \\
\text { difference between the } \\
\text { means } \\
\text { (p value) }\end{array}$ \\
\hline within overlapping \\
zone
\end{tabular}

Table 2: Statistical Analysis of sterna of both sexes.

\begin{tabular}{|c|c|c|c|}
\hline & Male Sternum & $\begin{array}{c}\text { Female } \\
\text { Sternum }\end{array}$ & $\begin{array}{c}\text { P value (level of } \\
\text { significance) }\end{array}$ \\
\hline Actual sample & 46 & 19 & \\
\hline By Hyrtl's law & 41 & 4 & $\begin{array}{c}0.8 \\
\text { (not significant) }\end{array}$ \\
\hline $\begin{array}{c}\text { No. and \% of specimen } \\
\text { obeying Hyrtl's Law }\end{array}$ & $41(89.130 \%)$ & $4(21.05 \%)$ & \\
\hline
\end{tabular}

Table 3: Showing age group wise and sex wise distribution of total cases.

\begin{tabular}{|c|c|c|c|c|c|c|c|}
\hline Group & I & II & III & IV & V & VI & VII \\
\hline Age(yrs) & Oct-20 & $20-30$ & $30-40$ & $40-50$ & $50-60$ & $60-70$ & $70-80$ \\
\hline Male Sternum & 11 & 13 & 11 & 3 & 5 & 2 & 1 \\
\hline Female Sternum & 4 & 6 & 4 & 3 & 0 & 1 & 1 \\
\hline Total & 15 & 19 & 15 & 6 & 5 & 3 & 2 \\
\hline
\end{tabular}

Table 4: Combined length of the sternum in male and female.

\begin{tabular}{|c|c|c|c|}
\hline \multicolumn{2}{|c|}{ Male Sternum } & \multicolumn{2}{c|}{ Female Sternum } \\
\hline $\begin{array}{c}\text { Interval of } \\
\text { sternum } \\
(\mathrm{mm})\end{array}$ & Frequency & $\begin{array}{c}\text { Interval of } \\
\text { sternum } \\
(\mathrm{mm})\end{array}$ & Frequency \\
\hline $110-119$ & 0 & $100-109$ & 1 \\
\hline $120-129$ & 4 & $110-119$ & 0 \\
\hline $130-139$ & 7 & $120-129$ & 1 \\
\hline $140-149$ & 7 & $130-139$ & 2 \\
\hline $150-159$ & 9 & $140-149$ & 7 \\
\hline $160-169$ & 13 & $150-159$ & 4 \\
\hline $170-179$ & 6 & $160-169$ & 4 \\
\hline Total & 46 & Total & 19 \\
\hline
\end{tabular}

Table 5: Showing Interval of Sternal Index in Males and Females.

\begin{tabular}{|c|c|c|c|}
\hline S. no & $\begin{array}{c}\text { Interval of Sternal } \\
\text { Index }\end{array}$ & $\begin{array}{c}\text { Male } \\
\text { Sternum }\end{array}$ & $\begin{array}{c}\text { Female } \\
\text { Sternum }\end{array}$ \\
\hline 1 & $30-35$ & 6 & 5 \\
\hline 2 & $36-40$ & 8 & 5 \\
\hline 3 & $41-45$ & 12 & 3 \\
\hline 4 & $46-50$ & 17 & 3 \\
\hline 5 & $51-55$ & 1 & 3 \\
\hline 6 & $56-60$ & 2 & 0 \\
\hline & Total & 46 & 19 \\
\hline
\end{tabular}

Int J Anat Res 2019, 7(4.2):7070-79. ISSN 2321-4287

\section{DISCUSSION}

The measurement of sternum done by many authors, regarding the sexual differences in the length of manubrium, mesosternum and combined length of manubrium and mesosternum are given in the table no 6.

Length of the Manubrium: The present study ,we observe that although the difference between the average length of male and female manubria is $3.26 \mathrm{~mm}$ which is statistically not significant ( $p-0.07)$, this parameter is not so helpful for sexing the sternum, because in this study $73.68 \%$ cases lie in overlapping zone. This is in accordance with Ashley(1956) [2] and Jit et al(1980) [4]. Dwight(1890) observed that the variations in the length of manubrium in two sexes to be very small.

Length of the Mesosternum: In the present study, the average difference in the length of mesosternum between male and female is 2.4 $\mathrm{mm}$ which is statistically significant ( $p-0.001)$. The length of mesosternum is extremely useful in determining the sex of sterna because the length of mesosternum is twice or more the length of manubrium in both sexes. These findings are co-related with Ashley (1956) [2] and Jit et al (1980) [4].

\section{Combined Length of manubrium and} Mesoternum: Ashley (1956) [2] concluded that the average combined length $(\mathrm{M}+\mathrm{B})$ in European sterna to be $156.9 \mathrm{~mm}$ in males and $138.7 \mathrm{~mm}$ in females, giving a difference of $18.2 \mathrm{~mm}$. He observed that a combined length of $149 \mathrm{~mm}$ was the dividing line between the male sternum and female sternum. As per Ashley "The 149 rule', was applicable to $76.7 \%$ male and $80.4 \%$ female European sterna. Similarly for East Africans he derived "The 136 rule" was applicable 
Table 6: Sexual Differences by various workers in the lengths of the manubria, mesosterna \& combined lengths of manubria \& Mesosternum.

\begin{tabular}{|c|c|c|c|c|c|c|c|c|c|}
\hline & & & & \multicolumn{2}{|c|}{ Manubrium(M) } & \multicolumn{2}{|c|}{ Mesosternum(B) } & \multicolumn{2}{|c|}{$\begin{array}{c}\text { Manubrium + } \\
\text { Mesosternum }(\mathrm{M}+\mathrm{B})\end{array}$} \\
\hline S No & Authors & $\begin{array}{c}\text { Sex } \\
\text { M-Male } \\
\text { F-Female }\end{array}$ & $\begin{array}{c}\text { No of } \\
\text { specimen }\end{array}$ & $\begin{array}{c}\text { Mean } \\
\text { Length } \\
(\mathrm{mm})\end{array}$ & $\begin{array}{c}\text { Diff } \\
\text { Length in } \\
\text { mean }\end{array}$ & $\begin{array}{c}\text { Mean } \\
\text { Length } \\
(\mathrm{mm})\end{array}$ & $\begin{array}{l}\text { Diff Length } \\
\text { in mean }\end{array}$ & $\begin{array}{c}\text { Mean } \\
\text { Length } \\
(\mathrm{mm})\end{array}$ & $\begin{array}{l}\text { Diff Length } \\
\text { in mean }\end{array}$ \\
\hline 1 & Dwight (1881) & $\begin{array}{l}M \\
F\end{array}$ & $\begin{array}{l}30 \\
26\end{array}$ & $\begin{array}{l}51.8 \\
46.7\end{array}$ & 5.1 & $\begin{array}{c}105.9 \\
89.4\end{array}$ & 16.5 & - & - \\
\hline 2 & Strauch (1881) & $\begin{array}{c}M \\
F\end{array}$ & $\begin{array}{c}200 \\
-\end{array}$ & - & - & $\begin{array}{c}110 \\
90\end{array}$ & 20 & - & - \\
\hline 3 & Dwight (1890) & $\begin{array}{l}M \\
F\end{array}$ & $\begin{array}{l}142 \\
86\end{array}$ & $\begin{array}{l}53.7 \\
49.4\end{array}$ & 4.3 & $\begin{array}{c}110.4 \\
91.9\end{array}$ & 18.5 & $\begin{array}{l}164.1 \\
141.3\end{array}$ & 22.8 \\
\hline 4 & Paterson (1904) & $\begin{array}{l}M \\
F\end{array}$ & $\begin{array}{l}310 \\
126\end{array}$ & $\begin{array}{c}52 \\
47.3\end{array}$ & 4.7 & $\begin{array}{c}103.7 \\
91\end{array}$ & 12.7 & - & - \\
\hline 5 & Ashley African (1956) & $\begin{array}{l}M \\
F\end{array}$ & $\begin{array}{l}85 \\
13\end{array}$ & $\begin{array}{l}45.9 \\
44.2\end{array}$ & 1.7 & $\begin{array}{l}96.5 \\
82.9\end{array}$ & 13.6 & $\begin{array}{l}142.6 \\
127.1\end{array}$ & 15.5 \\
\hline 6 & Ashley European (1956) & $\begin{array}{l}M \\
F\end{array}$ & $\begin{array}{l}378 \\
168\end{array}$ & $\begin{array}{l}52.2 \\
47.9\end{array}$ & 4.3 & $\begin{array}{c}104.7 \\
90.8\end{array}$ & 13.9 & $\begin{array}{l}158.9 \\
138.7\end{array}$ & 18.2 \\
\hline 7 & Jit etal (1980) & $\begin{array}{l}M \\
F\end{array}$ & $\begin{array}{c}312 \\
88\end{array}$ & $\begin{array}{l}51.73 \\
48.42\end{array}$ & 3.31 & $\begin{array}{c}95.35 \\
78.6\end{array}$ & 16.75 & $\begin{array}{l}147.08 \\
127.02\end{array}$ & 20.06 \\
\hline 8 & Dahipale et al (2002) & $\begin{array}{c}M \\
F\end{array}$ & $\begin{array}{l}96 \\
47\end{array}$ & $\begin{array}{l}48.42 \\
43.78\end{array}$ & 4.64 & $\begin{array}{l}94.43 \\
70.19\end{array}$ & 24.23 & $\begin{array}{c}142.2 \\
113.87\end{array}$ & 29.32 \\
\hline 9 & Gautam et al (2003) & $\begin{array}{c}M \\
F\end{array}$ & $\begin{array}{l}56 \\
44 \\
\end{array}$ & $\begin{array}{l}53 \\
48 \\
\end{array}$ & 5 & $\begin{array}{l}95 \\
76 \\
\end{array}$ & 19 & $\begin{array}{l}149 \\
124 \\
\end{array}$ & 25 \\
\hline 10 & Mahajan et al(2009) & $\begin{array}{c}M \\
F\end{array}$ & $\begin{array}{l}98 \\
55\end{array}$ & $\begin{array}{l}57.86 \\
46.96\end{array}$ & 10.9 & $\begin{array}{c}115.19 \\
93.85\end{array}$ & 21.34 & $\begin{array}{l}173.05 \\
140.82\end{array}$ & 32.23 \\
\hline 11 & Puttabanthi et al(2012) & $\begin{array}{c}\mathrm{M} \\
\mathrm{F}\end{array}$ & $\begin{array}{l}57 \\
22 \\
\end{array}$ & $\begin{array}{l}47.48 \\
21.68 \\
\end{array}$ & 25.8 & $\begin{array}{l}92.36 \\
88.95\end{array}$ & 3.41 & $\begin{array}{l}139.55 \\
110.64 \\
\end{array}$ & 28.91 \\
\hline 12 & Present study 2015 & $\begin{array}{c}M \\
F\end{array}$ & $\begin{array}{l}46 \\
19\end{array}$ & $\begin{array}{c}46.26 \\
43\end{array}$ & 3.26 & $\begin{array}{l}107.08 \\
104.68\end{array}$ & 2.4 & $\begin{array}{c}153.087 \\
147.68\end{array}$ & 5.407 \\
\hline
\end{tabular}

to $77.6 \%$ male and $84.6 \%$ female sterna.

He shows that coextensive range of the two sexes in European sterna extends from $126 \mathrm{~mm}$ to $171 \mathrm{~mm}$.. The co-extensive range covered 341 out of 378 male (90.2\%) and 153 out of 160 female (91.1\%) sterna. Jit et al (1980) [4] observed that the combined length is extremely useful in determining the sex of North Indian sterna. The average difference between the means is $20.06 \mathrm{~mm}$ which is statistically highly significant $(P<0.001)$. They also applied "the 136 rule", given by Ashley (1956) [2]. By which they determined the sex of $86 \%$ male and $78 \%$ female sterna. In our study, the difference between the average combined lengthof sternum is $5.407 \mathrm{~mm}$ which is statistically highly significant. The co-extensive range is $114-144 \mathrm{~mm}$ and by halving the same, we can come to "The 129 rule", similar to that given by Ashley (1956) [2].
By this rule $91.66 \%$ male and $82.97 \%$ female sterna can be identified correctly. In present study, the average combined length of manubrium and mesoaternum was $153.087 \mathrm{~mm}$ in males and $147.68 \mathrm{~mm}$ in females.

Measurements by various workers in the lengths of the manubria, mesosterna \& combined lengths of manubria \& mesosternum in males and females, given in table number 1.

\section{Manubrio - Corpus index (Sternal Index):} Wenzel (1788) concluded that the length of manubrium in male sternum and female sternum, is almost equal in length, but the mesosternum is longer in male sternum.. This led to enunciation of Hyrtl's law, according to which manubrio corpus index (sternal index) exceeds 50 in female sternum and is less than 50 in male sternum. Table No. 2 gives the percentage of cases obeying the Hyrtl's law in 
male sternum and female sternum.. In the present study, $21.05 \%$ female and $89.13 \%$ male specimens obey the Hyrtl's law. P value 0.8 , is not significant, this law is not helpful in determining the sex.

Ashley (1956) [2] and Jit et al (1980) [4] both concludes that the Hyrtl's law to be 'unreliable.' Table 7: Ability of Hyrtl's Law (M/B x $100=<50$ male sternum, $>50$ female sternum).

\begin{tabular}{|c|c|c|c|c|}
\hline Observer & Year & $\begin{array}{l}\text { Number of } \\
\text { specimen }\end{array}$ & $\begin{array}{c}\text { Sex } \\
\text { M -Male } \\
\text { F - Female }\end{array}$ & $\%$ Obeying law \\
\hline \multirow{2}{*}{ Dwight } & \multirow{2}{*}{1890} & 142 & $M$ & $59.10 \%$ \\
\hline & & 86 & $\mathrm{~F}$ & $60.40 \%$ \\
\hline \multirow{2}{*}{ Patermoller } & \multirow{2}{*}{1890} & 55 & $M$ & $65 \%$ \\
\hline & & 33 & $\mathrm{~F}$ & - \\
\hline \multirow{2}{*}{ Krause } & \multirow{2}{*}{1897} & - & $M$ & - \\
\hline & & 14 & $\mathrm{~F}$ & $43 \%$ \\
\hline \multirow{2}{*}{ Ashley African } & \multirow{2}{*}{1956} & 85 & $M$ & $64.70 \%$ \\
\hline & & 13 & $\mathrm{~F}$ & $69.20 \%$ \\
\hline \multirow{2}{*}{ Ashley European } & \multirow{2}{*}{1956} & 378 & $\mathrm{M}$ & $52.90 \%$ \\
\hline & & 171 & $\mathrm{~F}$ & $69.30 \%$ \\
\hline \multirow{2}{*}{ Narayan \& Verma } & \multirow{2}{*}{1958} & 126 & $M$ & $34.12 \%$ \\
\hline & & 27 & $\mathrm{~F}$ & $81.48 \%$ \\
\hline \multirow{2}{*}{ Jit etal } & \multirow{2}{*}{1980} & 312 & $M$ & $31.08 \%$ \\
\hline & & 88 & $\mathrm{~F}$ & $88.64 \%$ \\
\hline \multirow{2}{*}{ Dahipale et al } & \multirow{2}{*}{2002} & 96 & M & $52.20 \%$ \\
\hline & & 47 & $\mathrm{~F}$ & $100 \%$ \\
\hline \multirow{2}{*}{ Atal et al. } & \multirow{2}{*}{2008} & 56 & $M$ & \\
\hline & & 44 & $\mathrm{~F}$ & $75 \%$ \\
\hline \multirow{2}{*}{ Puttabanthi et al. } & \multirow{2}{*}{2012} & 57 & $M$ & $94.73 \%$ \\
\hline & & 22 & $\mathrm{~F}$ & $4.54 \%$ \\
\hline \multirow{2}{*}{ Present study } & \multirow{2}{*}{2015} & 46 & M & $89.13 \%$ \\
\hline & & 19 & F & $21.05 \%$ \\
\hline
\end{tabular}

Discriminant Function Analysis: In the present study, we subjected our data to multivariate discriminant analysis technique as given by Armitage (1971) and by this method $61.5 \%$ were classified correctly sterna can be sexed correctly. Penrose (1947) and Jit et al (1980) [4] by multivariate analysis, they observed $89 \%$ male and $82 \%$ female sterna could be sexed correctly.

Dahiphale V P, Baheete B H, Kamkhedkar S G. (2002), observed that the length of mesosternum (B) distinguishes $69.80 \%$ male sternum and $76.60 \%$ female sterna and with the combined length of manubrium and mesosternum (M+B) $38.54 \%$ male and $57.45 \%$ female sterna can be sexed correctly. By applying the multivariate linear discriminant analysis technique $92 \%$ male and $87 \%$ female sterna can be sexed correctly. If the length of mesosternum was more than $88 \mathrm{~mm}$, the sternum was male and if less than $76 \mathrm{~mm}$, it was female sternum. By its measurement $69.80 \%$ male and $76.60 \%$ female sterna could be sexed.

The combined length of manubrium and mesosternum could also determine the sex correctly in $38.54 \%$ male and $57.45 \%$ female specimens [5].

In present study, the length of mesosternum (B) distinguishes $78.26 \%$ male sternum and $31.57 \%$ female sternum and with the combined length of manubrium and mesosternum (M+B) $60.86 \%$ male and $57.89 \%$ female sterna can be sexed correctly. By applying the multivariate linear discriminant analysis technique $61.5 \%$ were classified correctly sterna can be sexed correctly. If the length of mesosternum was more than $100 \mathrm{~mm}$, the sternum was male and if less than $100 \mathrm{~mm}$, it was female.

But overlapping zone in both sexes $(21.73 \%$ males and $68.42 \%$ females). The combined length of manubrium and mesosternum could also determine the sex correctly in $60.86 \%$ male and $57.89 \%$ female specimens.

Gautam R S, Shah G V, Jadav H R, Gohil B J(2003) they concluded that the length of manubrium, it is in the range of $35 \mathrm{~mm}$ to $70 \mathrm{~mm}$ in male sternum and $40 \mathrm{~mm}$ to $61 \mathrm{~mm}$ in female sternum. The mean length of manubrium is 53 $\mathrm{mm}$ in males and $44 \mathrm{~mm}$ in females. The combined length of manubrium \& body of sternum ranges from $101 \mathrm{~mm}$ to $192 \mathrm{~mm}$ in male and $98 \mathrm{~mm}$ to $150 \mathrm{~mm}$ in female. The combined mean length of manubrium and mesosternum was $149 \mathrm{~mm}$ in male and $124 \mathrm{~mm}$ in females. If the length of the manubrium is less then $33 \mathrm{~mm}$ then it is of a female sternum, if it is above 63 $\mathrm{mm}$ it is of a male sternum. If the length of the body of sternum is less than $48 \mathrm{~mm}$ then it is of female sternum, if it is more than $106 \mathrm{~mm}$ then it is male sternum. If the combined length of a sternum is less than $92 \mathrm{~mm}$ then it is of female sternum where as if it exceeds $161 \mathrm{~mm}$, it is of male sternum [1].

In present study, the combined length of manubrium \& body of sternum ranges from 123 $\mathrm{mm}$ to $179 \mathrm{~mm}$ in male sternum and $101 \mathrm{~mm}$ to $167 \mathrm{~mm}$ in female sternum. The combined mean length of manubrium and mesosternum was $153.043 \mathrm{~mm}$ in male sternum and $147.68 \mathrm{~mm}$ in female sternum.

If the length of the manubrium is less then 
Rashmi Jaiswal STERNUM AS AN INDEX FOR DETERMINATION OF SEX.

\begin{tabular}{|c|c|c|c|c|c|c|c|}
\hline \multirow{6}{*}{$\begin{array}{c}\text { Table 8: Mean length } \\
\text { of various parts of } \\
\text { sternum. }\end{array}$} & S. No & Worker & Sex & $\begin{array}{c}\text { No of } \\
\text { specimen }\end{array}$ & $\begin{array}{l}\text { Length of } \\
\text { manubrium } \\
(\mathrm{mm})\end{array}$ & $\begin{array}{l}\text { Length of } \\
\text { mesosternum } \\
\text { (mm) }\end{array}$ & $\begin{array}{c}\text { Combined } \\
\text { length }(\mathrm{mm})\end{array}$ \\
\hline & 1 & Dwight (1881) & $\begin{array}{l}M \\
F\end{array}$ & $\begin{array}{l}30 \\
26 \\
\end{array}$ & $\begin{array}{l}51.8 \\
46.7\end{array}$ & $\begin{array}{c}105.9 \\
89.4\end{array}$ & $\begin{array}{l}157.7 \\
136.1\end{array}$ \\
\hline & 2 & Dwight (1890) & $\begin{array}{l}M \\
F\end{array}$ & $\begin{array}{c}142 \\
86 \\
\end{array}$ & $\begin{array}{l}53.7 \\
49.4\end{array}$ & $\begin{array}{c}110.4 \\
91.9\end{array}$ & $\begin{array}{l}164.1 \\
141.3\end{array}$ \\
\hline & 3 & Ashley (1956) & $\begin{array}{l}M \\
F\end{array}$ & $\begin{array}{l}85 \\
13\end{array}$ & $\begin{array}{l}45.9 \\
44.2\end{array}$ & $\begin{array}{l}96.5 \\
82.9\end{array}$ & $\begin{array}{l}142.6 \\
127.1\end{array}$ \\
\hline & 4 & Jit (1986) & $\begin{array}{l}M \\
F\end{array}$ & $\begin{array}{c}312 \\
88\end{array}$ & $\begin{array}{l}51.73 \\
48.42\end{array}$ & $\begin{array}{c}95.35 \\
78.6\end{array}$ & $\begin{array}{l}147.08 \\
127.02\end{array}$ \\
\hline & 5 & Present study & $\begin{array}{c}M \\
F\end{array}$ & $\begin{array}{l}46 \\
19\end{array}$ & $\begin{array}{c}46.26 \\
43\end{array}$ & $\begin{array}{l}107.08 \\
104.68\end{array}$ & $\begin{array}{c}153.087 \\
147.68\end{array}$ \\
\hline
\end{tabular}

$40 \mathrm{~mm}$ then it is of a female sternum. If it is exceeds $40 \mathrm{~mm}$ it is of a male sternum. If the length of the body of sternum is less than 100 $\mathrm{mm}$ then it is of female, if it is more than $100 \mathrm{~mm}$ then it is male. If the combined length of a sternum is less than $150 \mathrm{~mm}$ then it is of female where as if it exceeds $150 \mathrm{~mm}$, it is of male. Table no 3 shows Mean length of various parts of sternum in different authors studies with the present study.

Robert Selthofer, Vasilije Nikoli, and etal(2006), Morphometric analyses showed that the proportional sternum structure in the females and in the males is equal. Indexes of manubrium length proportion as well as of body of the sternum length proportion are almost identical in sterni of both sexes. There is no statistical significance in sternal angle value [6]. Our study shows same observations.

D K. Atal, A. Murari etal(2008) they observed that sternal index was not reliable in sex determination. The mean sternal index for male was 46.089 and female was 56.703. The level of significance of the difference between the means was statistically highly significant $(p<$ $0.001)$ for sternal index. Out of 56 males sternums, 34 male cases (60.71\%) were lying in overlapping zone while of the 44 female cases, 40 cases (90.91\%) were lying in overlapping zone. Only 22 male and 4 female cases were not lying in the overlapping zone $89.28 \%$ male and $75.00 \%$ female specimens obey the Hyrtl's Law [7].

In present study, the mean sternal index for male was 43.43 and female was 41.132. Jagmahender Singh, Dalbir Singh, RK(2010) they observed that the combined length of manubrium and mesosternum is the reliable and useful estimator of sex in human sternal measurement. The mean length of manubrium for male sternum was 52.1 $\mathrm{mm}$ and of female sternum was $47.17 \mathrm{~mm}$. The difference between means of male and female manubrial length was 7.79 which was statistically high $(p<0.0001)$, on the basis of this only $12.3 \%$ males and $16.48 \%$ females were identified. Mean mesosternal length in males was $94.07 \mathrm{~mm}$ and in females sternum it was 78.54 $\mathrm{mm}$, the difference in the means for length of mesosternum of two sexes was found to be 12.49 , which was highly significant. The combined length of manubrium and mesosternum for male sterna was $145.69 \mathrm{~mm}$ and for female was $124.87 \mathrm{~mm}$. Sternal index of male sternum was 56.13 and for female was $61.23 \mathrm{~mm}$ [8].

In present study, the mean length of manubrium for male sternum was $46.26 \mathrm{~mm}$ and of female sternum was $43 \mathrm{~mm}$. The difference between means of male and female manubrial length was 3.26 , statistically significant $82.6 \%$ males and $26.31 \%$ females were identified. Mean mesosternal length in males was $107.08 \mathrm{~mm}$ whereas in females sternum it was $104.68 \mathrm{~mm}$, the difference in the means for length of mesosternum of two sexes was 2.4, which was significant. The combined length of manubrium and mesosternum for male sterna was 153.087 $\mathrm{mm}$ and for female was $147.68 \mathrm{~mm}$. Sternal index of male sternum was 43.43 and for female was $41.132 \mathrm{~mm}$.

Osunwoke E.A, Gwunireama I.U (2010) they found that average mean length of male and female manubrium was $60.7 \pm 10.7 \mathrm{~mm}$ and 46.0 $\pm 6.13 \mathrm{~mm}$, respectively. The average mean length of the male and female mesosternum was 
$101.3 \pm 13.22 \mathrm{~mm}$ and $77.9 \pm 7.07 \mathrm{~mm}$, respectively. The combined length of the manubrium and mesosternum for male and females was $164.6 \pm 19.96 \mathrm{~mm}$ and $123.3 \pm 11.8 \mathrm{~mm}$, respectively. The length of the mesosternum distinguishes $89.70 \%$ males and $61.5 \%$ females while the combined length of the manubrium and mesosternum distinguished $94.11 \%$ males and $9.23 \%$ females, detects sex correctly. The length of the manubrium was not useful in sexual dimorphism of the Sternum [9].

In present study, that average mean length of male and female manubrium was $46.26 \mathrm{~mm}$ and $43 \mathrm{~mm}$ respectively. The average mean length of the male and female mesosternum was $107.08 \mathrm{~mm}$ and $104.68 \mathrm{~mm}$ respectively. The combined length of the manubrium and mesosternum for male and females was $153.087 \mathrm{~mm}$ and $147.68 \mathrm{~mm}$, respectively. With combined length $61.5 \%$ sternum were classified correctly.

Sirisha Puttabanthi, Dr. Subhadra Devi Velichety(2012), according to them length of manubrium may act as a good discriminator of female sterna as it is showing $100 \%$ of accuracy. Combined mean length of manubrium and mesosternum acts as a best discriminator to sex unknown sterna. By application of binary logistic multivariate discriminant analysis technique $95 \%$ male and $45 \%$ female sterna can be sexed correctly [10].

Adhvaryu Ankit V, Adhvaryu Monika (2013) they found that if the length of manubrium was less than $39.61 \mathrm{~mm}$ then it was of female sternum and if it was more than $53.30 \mathrm{~mm}$ then it was of male sternum. If the length of mesosternum was less than $67.78 \mathrm{~mm}$ then it was of female and if it was more than $94.20 \mathrm{~mm}$ then it was of male. If the combined length of manubrium and mesosternum was less than $107.39 \mathrm{~mm}$ then it was of female sternum and if it was more than $143.69 \mathrm{~mm}$ then it was of male sternum. "The Rule of 136" given by Ashley (1956) was applied to determine the sex of sterna and to determine the number of male and female sterna obeying the rule. Statistically significant difference in mean values of length of manubrium, length of mesosternum and combined length of both sexes was observed. "Rule of 136" determined 34 male sternum and 66 female sterna, while $71.11 \%$ (32) of male sterna and $96.34 \%$ (53) of female sterna obeyed the rule. They concluded combined length of manubrium and mesosternum was the best discriminating parameter of sex and Rule of 136 was helpful in determination of sex [11].

In present study, If the length of manubrium was less than $40 \mathrm{~mm}$ then it was of female sternum and if it was more than $40 \mathrm{~mm}$ then it was of male sternum. If the length of mesosternum was less than $100 \mathrm{~mm}$ then it was of female sternum and if it was more than $100 \mathrm{~mm}$ then it was of male sternum. If the combined length of manubrium and mesosternum was less than 150 $\mathrm{mm}$ then it was of female sternum and if it was more than $150 \mathrm{~mm}$ then it was of male sternum. Adhvaryu Ankit V, Adhvaryu Monika A(2013) observed that the mean sternal index in male sternum and female sternum were 53.68 and 56.91 respectively. The difference in mean of sternal index in two sexes was 3.23 which was statistically significant $(p<0.05)$. It was also observed that $31.11 \%$ male (14) and $81.81 \%$ female (45) specimens obeyed the Hyrtl's law which was similar with findings of Narayan and Verma (1958) and Jit et al.(1980). On applying chi-square test, $p$ value was less than 0.008 . On applying Hyrtl's law to the sample, it gave 24 male sternum and 76 female sternum while the actual sample size was 45 male and 55 female. On applying chi-square test it was found that $p<0.002$, which indicated that this difference in observation was highly significant and this law was not helpful in determining the sex of an individual specimen [11].

In present study, the mean sternal index for male sternum and female sternum were 43.43 and 41.132 respectively. The difference in mean of sternal index in two sexes was 2.298 which was not statistically significant ( $p-0.8)$.

Kaneriya D, Suthar K(2013) they found that the lengths of the manubrium in the male sterna vary from $35 \mathrm{~mm}$ to $71 \mathrm{~mm}$. The Mean was calculated and found to be $52 \mathrm{~mm}$. The Standard Deviation (S.D.) for the length of the manubrium for males is \pm 8 . The lengths of manubrium in the female sterna vary in the range of $41 \mathrm{~mm}$ to $61 \mathrm{~mm}$. The Mean is $48 \mathrm{~mm}$ and the S.D. is \pm 5 . The lengths of the body in male sterna were in the range of $59-133 \mathrm{~mm}$. The Mean is $98 \mathrm{~mm}$ and S.D. \pm 18 . The lengths of 
the body in female sterna were in the range of $56-96 \mathrm{~mm}$. The combined lengths $(M+B)$ in the male cases are in the range from 101-191 mm. The combined lengths in the female cases are in the range from $98-150 \mathrm{~mm}$, the sternal indices for males are in range of $38-77 \mathrm{~mm}$ while the female cases are in the range $46-78 \mathrm{~mm}$ [12].

In present study, the lengths of the manubrium in the male sterna vary from $34 \mathrm{~mm}$ to $60 \mathrm{~mm}$ and the Mean was $46.26 \mathrm{~mm}$. The Standard Deviation (S.D.) for the length of the manubrium for males is 6.8164337 . The lengths of manubrium in the female sterna vary in the range of $32 \mathrm{~mm}$ to $54 \mathrm{~mm}$. and Mean is $43 \mathrm{~mm}$ and the S.D. is 6.377. The lengths of the body in male sterna were in the range of $86-127 \mathrm{~mm}$. The Mean is $107.08 \mathrm{~mm}$ and S.D. 11.37800234. The lengths of the body in female sterna were in the range of $69-125 \mathrm{~mm}$. The mean was 104.68 and SD - 13.258. The combined lengths $(M+B)$ in the male cases are in the range from 123-179 $\mathrm{mm}$. the mean was 153.087 and SD was 14.972. The combined lengths in the female cases are in the range from 101-167 mm. the mean was 147.68 and SD was 15.62. The sternal indices for males are in range of $31.4-60 \mathrm{~mm}$, mean was 43.43 and SD was 6.5, while the female cases are in the range $32.2-52.63 \mathrm{~mm}$, mean was 41.132 and SD was 7.18.

Mohit V Changani, Jatin Chudasama etal (2014) they concluded that for males, sternal area was found to be most accurate criterion to identify sex by the method of identification point. By using this criterion, $59.64 \%$ specimens were correctly identified as male, whereas $17.54 \%$ specimens were correctly identified by using the sternal width. Overall, $40.35 \%$ specimens were falling in the overlapping zone for the sternal area, which is suggestive of the higher accuracy of the criteria for the determination of sex[13].

\section{CONCLUSION}

The present study concluded that the combined length of manubrium and mesosternum is the most reliable criteria for determination of the sex of a sternum out of all the paramaters, with combined length of sternum $61.5 \%$ were classified correctly.
By applying the multivariant linear discriminant analysis(D) technique: When $D$ is more than -0.106 , it is male sternum, when $D$ is less than -0.106 , it is female sternum. $61.5 \%$ were classified correctly.

$\begin{array}{lll}\text { Sensitivity } & - & 56.5 \% \\ \text { Specificity } & - & 73.7 \% \\ \text { Positive Predicted Value } & - & 83.87 \% \\ \text { Negative Predicted Value } & - & 41.17 \%\end{array}$

If the length of the manubrium is less than 40 $\mathrm{mm}$ then it is of a female. It is exceeds $40 \mathrm{~mm}$ it is of a male. But $17.39 \%$ males and $73.68 \%$ females are in overlapping zone.

If the length of the mesosternum is less than $100 \mathrm{~mm}$ then it is of female sternum, if it is more than $100 \mathrm{~mm}$ then it is male sternum. But $21.73 \%$ males and $68.42 \%$ females are in overlapping zone.

If the combined length of a sternum is less than $150 \mathrm{~mm}$ then it is of female sternum where as if it exceeds $150 \mathrm{~mm}$, it is of male sternum. But $39.13 \%$ male sternum and $42.1 \%$ female sternum are in overlapping zone.

Sternal index was also found to be unreliable in sex determination. The mean Sternal Index in male sternum was 43.43 and in female sternum 41.132. $89.13 \%$ of male and $21.05 \%$ of female specimen obey the Hyrtl's law.

The present study concludes:

1. Length of manubrium may act as a good discriminator of female sterna.

2. Combined mean length of manubrium and body of the sternum acts as a best discriminator to sex unknown sterna.

3. By application of binary logistic multivariate discriminant analysis technique $95 \%$ male and $45 \%$ female sterna can be sexed correctly.

Out of all the parameters of sterna, combined length of manubrium and mesosternum is the most important parameter which when applied to an individual specimen can help in sexing the sterna correctly in our study.

\section{Conflicts of Interests: None}

\section{REFERENCES}

[1]. Gautam RS, Shah GV, Jadav HR, Gohil, B.J. The Human Sternum - as An Index of Age \& Sex. Anat. Soc. India 2003;52(1):20-23. 
[2]. Ashley GT. Typing of the human sternum -the influence of sex and age on its measurement. Journal of Forensic Medicine 1956; 3:27-43.

[3]. Vijay Kumar R. Waghmare, Rupali B. Gaikwad, Vaibhav Sonar. Determination of the age with the help of ossification of the sternum. Int J Pharm Biomed Res 2012;3(1), 5-6.

[4]. Jit I, Jhingan V and Kulkarni M. Sexing the human sternum. American Journal of Physical Anthropology 1980; 53:217-224.

[5]. Dahiphale V P, Baheete B H, Kamkhedkar S G. Sexing The Human Sternum In Marathwada Region. J Anat. Soc. India 2002;51(2):162-167.

[6]. Selthofer R, Nikoliæ V, Mrcela T, Radiæ R, Leksan I, Rudez I, Selthofer K. Morphometric analysis of the sternum. Coll Antropol. 2006 Mar;30(1):43-7.

[7]. D.K. Atal, A. Murari, S.K. Naik. Role of Sternal Index in Determination of Gender. Indian Journal of Forensic Medicine and Pathology. July-December 2008;1(3\&4).

[8]. Jagmahender Singh, Dalbir Singh, RK Padhak. Gender determination from sternal measurements in Northwest Indian subjects. Journal Indo-Pacific Academy of forensic odontology 2010;1:20-29.

[9]. Osunwoke E A, Gwunireama I U, Orish C N, Ordu K S, Ebowe I. A study of sexual dimorphism of the human sternum in the southern Nigerian population. Journal of Applied Biosciences 2010;26:1636 1639,ISSN 1997-5902.
[10]. Sirisha Puttabanthi, Dr. Subhadra Devi Velichety, Dr. Tirupati rao Padi, Dr. Ravindra Kumar Boddeti, J. Ratna Priyanka. Sexing of unknown adult human sterna by metrical analysis. Int J Biol Med Res. 2012;3(2):1516-1519.

[11]. Adhvaryu Ankit V, Adhvaryu Monika A, Rathod Suresh P, Chauhan Pradip R, Joshi Hemang G. Study of sexual dimorphism in human sterna. International Journal of Medical Research \& Health Sciences www.ijmrhs.com, $13^{\text {th }}$ June, 2013, Volume 2 Issue 3 July - Sep. and Int J Med Res Health Sci. 2013;2(3): 577-581.

[12]. Kaneriya D, Suthar K, Patel V, Umarvanshi B, Mehta $C$ and Tailor $C$. Morphometric study of sternum for determination of sex. Cibtech Journal of Bio-Protocols ISSN: 2319-3840 (Online) An Online International Journal Available at http://www.cibtech.org/ cjbp.htm 2013;2(2):6-13.

[13]. Mohit V Changani, Jatin Chudasama, Dhaval Talsaniya, Jignesh Vadgama, Balkrishna Thummar, T C Singel. Determination of sex from the width and the area of human sternum \& manubrium in Gujarat population. Journal of Research in Medical and Dental Science July - September 2014;2(3):13-18.

\section{How to cite this article: \\ Rashmi Jaiswal STERNUM AS AN INDEX FOR DETERMINATION OF SEX. Int J Anat Res 2019;7(4.2):7070-7079. DOI: 10.16965/ ijar.2019.307}

